\title{
Timne Language
}

National Cancer Institute

\section{Source}

National Cancer Institute. Timne Language. NCI Thesaurus. Code C154160.

A Niger-Congo language spoken in Sierra Leone. 